\title{
VERGİ HATALARI VE DÜZELTME YOLLARI: HÜKÜM VE SONUÇLARI AÇISINDAN BİR DEĞERLENDİRILMESİ
}

\section{Mutlu YORULDU}

Özet

Vergi Usul Kanunu'nun (VUK) 116'1nc1 maddesinde vergi hatalar1; “vergiye ilişkin hesaplarda veya vergilendirmede yapllan hatalar yüzünden haksı yere fazla veya eksik vergi istenmesi veya alınması" şeklinde tanımlanmaktadır. Hatanın neden olduğu sonuçlar gerçek sonuçlar olmayarak gerekli düzeltme işlemleri sonucunda gerçek sonuca varılması gerekmektedir. Vergi hatalarının ivedi biçimde ortadan kaldırılmaması durumunda devlet hazinesi açısından vergi kaybı doğabilecek ya da vergi mükellefi hak mahrumiyeti yaşayabilecektir. Vergi hatalarının giderilmemesi durumunda aynı zamanda VUK 3'üncü maddesinde belirtilen ve vergilendirme işlemlerinin temel hükümlerinden olan "vergilendirmede vergiyi doğuran olay ve bu olaya ilişkin muamelelerin gerçek mahiyeti esastır” hükmüne aykırılık doğmuş olacaktır. Diğer taraftan Anayasa'nın "vergi ödevi” başlıklı 73'üncü maddesinin 2'nci fikrasında belirtilen ve vergi politikasının amaçlarından olan "vergi yükünün adaletli ve dengeli dağılımı, maliye politikasının sosyal amacıdır" ilkesiyle bağdaşmayarak, Anayasa'ya aykırılık söz konusu olabilecektir. Bu çalışmada vergi hatalarının muhteviyatı ile birlikte hüküm ve sonuçları üzerinde durulmuş ve özellikle VUK ve Anayasa Hukuku açısından olası tartışmalı durumlardan bahsedilmiştir.

Anahtar Kelimeler: Vergi Hatası, Düzeltme, Hüküm ve Sonuçları

Jel Kodları : K34, H83, H29.

\section{TAX ERRORS AND CORRECTION METHODS: AN ASSESSMENT OF PROVISIONS AND CONSEQUENCES}

\begin{abstract}
Tax errors are characterized in Article 116 of the Tax Procedure Act (VUK) is defined as "unjustly request or receive over-or under tax due to errors in tax-related accounts or taxation". The results caused by the error should be rectified with the necessary corrections, and the real results should be reached. If tax errors are not eliminated as a matter of time, tax loss may arise for the state treasury or the taxpayer may experience desensitization. If tax errors are not resolved, there will also be a violation of the provision of "the actual nature of the tax-related event and the treatment of this event is essential in taxation" shall be born out of the provisions of the taxation process specified in Article 3 of the VUK. On the other hand, there may be a violation of the Constitution by being incompatible with the principle of a "fair and balanced distribution of tax burden is the social purpose of fiscal policy", as set out in paragraph 2 of article 73 titled "Tax Duty" of the Constitution. In this study, the provision and consequences of
\end{abstract}

\footnotetext{
${ }^{1}$ Dr. Öğr. Üyesi Mutlu Yoruldu, Balıkesir Üniversitesi İIBBF Maliye Bölümü, e-posta: mutluyoruldu@gmail.com
} 
tax errors were discussed, and in particular, controversial cases in terms of VUK and Constitutional Law were examined.

Keywords: Tax Error, Correction, Provision and Consequences

Jel Codes: K34, H83, H29.

\section{GİRIŞ}

Devletlerin en önemli kamusal kaynağı olan vergiler oluşturmaktadır, Vergilendirmede devlet veya vergi idaresi vergi alacaklısı; verginin mükellefleri ise vergi borçlusunu konumundadırlar. Vergi idaresi, vergi alacağını zamanında tam ve doğru olarak mükelleflerden almak isterken; vergi mükellefleri ise genel olarak vergi ödememe veya ödemeleri gerekenden daha az ödeme veya vergi ödemelerini geciktirme eğiliminde olabilmektedirler. Vergilendirme nedeniyle vergi mükellefi olan kişilerin kullanılabilir gelirleri azaldığından, vergi idaresi ile vergi mükellefleri arasında vergilendirmeye ilişkin bazı hususlarda birtakım uyuşmazlıklar ortaya çıkabilmektedir. Söz konusu uyuşmazlık konularının çoğunluğu mükellef adına idare tarafından tarh ve tahakkuk ettirilen vergi aslı veya vergi cezasına ilişkin olmak ile birlikte sadece bununla sınırlı değildir. Vergi hataları, vergi idaresi tarafından gerçekleştirilen mükellefe ait vergilendirme işlemlerinde ortaya çıkan, sonuçları itibariyle hem vergi idaresine hem de vergi mükelleflerine belli düzeyde maliyet yüklemesi yapabilen hatalı işlemlerin tümünü ifade etmektedir. $\mathrm{Bu}$ hatalı işlemlerin kaynağının bulunarak vergi idaresi tarafindan zaman kaybetmeksizin giderilmesi tarafların mağduriyetinin ortadan kaldırılmasını sağlamakta ve vergi kuruma yönelik kişisel algının iyileşmesine tesir edebilmekte ve vergiye gönüllü uyum düzeyini etkileyebilmektedir. Vergi hataları, hesap hataları ve vergilendirme hataları olmak üzere iki ana grup altında toplanmaktadır. Hesap hatalarının tesiri; vergilendirmenin maddi ödevine ilişkin iken, vergilendirme hatalarının temel tesiri ise, vergilendirmenin şekli ödevlerine yöneliktir. Vergi hataları vergi idaresi ile vergi mükellefi arasında bir uyuşmazlık konusu olduğundan çözüme kavuşturulması, her iki tarafın da hak ve hukukunun korunması açısından önem arz etmektedir. Vergi hatalarından doğan uyuşmazlığın ortadan kaldırılabilmesi, hatanın idare tarafından giderilmesi ve telafi edilmesi ile ilgilidir. Çünkü hatalı işlemi yapan vergi idaresi olmaktadır. Vergi hataları iki türlü giderilebilmektedir. Bunlardan ilki, vergi hatasının barışçıl çözüm yolu olarak kabul edilen idari tarafın ilgili hata düzeltme işlemleri yapılarak uyuşmazlığın çözüme kavuşturulmasıdır. İkincisi ise, nezdinde vergilendirme ile ilgili hatalı işlem yapılan mükellefin uyuşmazlık konusunu vergi yargısına taşımasıdır. Bahsedilen ikinci yol her iki tarafa da zaman ve parasal maliyet yükleyeceğinden ve tarafları karşı karşıyak getireceğinden çok arzulanan bir yöntem olarak kabul edilmemektedir. Bu çalışmada vergi hataları ve düzeltme yolları ile hüküm ve sonuçları üzerinde durulmuştur. Çalışmanın amacı; vergi hatalarının idare tarafından düzeltilmemesi durumunda ortaya çıkan Vergi Usul Kanunu'na (VUK) ve Anayasaya aykırılık durumlarının tartışılmasıdır. Bu çalışma, nitelik araştırma yöntemlerinden betimleyici araştırma tekniği kullanılarak hazırlanmıştır. 


\section{VERGİ HATALARI}

Kişilerin iktisadi bir eylemde bulunurken, gerçekleştirdikleri veya gerçekleştirmeyi planladıkları eylemin neticesinde kişisel faydalarını arttırmayı amaçlamaktadırlar (Çamlı, 2020: 18). Dolayısıyla vergilendirmeyi kişilerin iktisadi faaliyetlerinin bir parçası olarak değerlendirdiğimizde kişiler aleyhine ortaya çıkan her sonuç ilgili vergi mükellefinin kazancının düşmesi ve faydasının azalması sonucunu doğurabilmektedir. Vergi hatalarının ortaya çıkması ve giderilmemiş olması, vergi adaletini bozucu etkisiyle birlikte gelir dağılımında eşitsizliğe neden olabilmekte sonuç olarak kişiler arası iktisadi eşitsizlik sarmalını tetikleyebilmektedir (Çaml1, 2020a: 207). Diğer taraftan vergi hatalarının ülkenin makroekonomik büyüklükleri ve dengeleri üzerindeki etkisini doğrudan ve kesin biçimde saptayabilmek oldukça güçtür (Keene ve Thomson, 2007: 2). VUK'un 116'1nc1 maddesinde vergi hataları; “vergiye ilişkin hesaplarda veya vergilendirmede yapllan hatalar yüzünden haksı yere fazla veya eksik vergi istenmesi veya alınması" şeklinde tanımlanmaktadır. Vergilendirme ile ilgili tüm aşamalarda ve işlemlerde vergi hatası meydana gelebilir (Demirel, 2016: 21). Vergi hataları, hesap hataları ve vergilendirme hataları olmak üzere iki ana grup altında incelenmektedir. Hesap hatalar1; vergi matrahında yapılan hatalar, vergi miktarında yapılan hatalar ve mükerrer vergilendirme olmak üzere üç türlüdür. Vergilendirme hataları ise; mükellefin şahsında hata, mükellefiyette hata, konuda (mevzuda) hata ve vergilendirme veya muafiyet döneminde hata olmak üzere dört alt başlı̆ga ayrılmaktadır.

\subsection{Hesap Hataları}

Hesap hataları; vergi miktarını etkileyen maddi hatalar ve verginin hesaplanmasına ilişkin yanlışlıkları ifade etmektedir (Öncel vd, 2014: 169-170). Hesap hataları rakamsal yanlışlıkları belirttiğinden aritmetik hatalar olarak da bilinmektedir (Perçin, 2007: 156). Hesap hatalarının neler olduğu VUK'un 117'nci maddesinde düzenlenmiştir. Buna göre; vergi matrahında hatalar, vergi miktarında hatalar ve mükerrer vergilemeden kaynaklanan hatalar olmak üzere üç gruba ayrılmıştır. Hesap hataları, tespit edilmesi ve ortaya çıkartılması vergilendirme hatalarına göre nispeten kolay olan, beyanname üzerinde yapıldığı için düzeltilmesinin de kolay olduğu hatalardır.

\subsubsection{Vergi Matrahında Yapılan Hatalar}

Vergilendirmede matrah hatas1; VUK'ta 117/1'inci maddesinde "Vergilendirme ile ilgili beyanname, tahakkuk fiși, ihbarname ve kararlarda matraha ait rakamlartn veya indirimlerin eksik veya fazla gösterilmiş veya hesaplanmış olmasıdır" şeklinde tanımlanmıştır. Vergilendirmede matrah belirleme usulü olarak genel geçer yöntem "beyan usulü" olduğundan, vergi mükellefleri vergi matrahlarını belirlerken matrahı belirleyen toplama çıkarma işlemlerinde hatalı işlemler gerçekleştirmiş olabilirler. Diğer taraftan vergi matrah eksikliğinin vergi idaresi tarafindan ikmalen ve re'sen belirlendiği durumlarda da benzer durumlar ortaya çıkabilir. Örneğin; yedi farklı irat ve kazanç unsurundan oluşabilen yıllık gelir vergisi matrahı belirlenirken; gelir vergisi mükellefinin kazancı olduğu halde ticari kazancını toplama dâhil etmemesi veya yanlış toplamaların yapılması vergi matrahının eksik veya fazla çıkmasına ve dolayısıyla vergi tarhiyatının eksik ve ya fazla olmasına sebep olabilir. İște bu ve benzeri örneklemeler matrah hatasını ifade etmektedir. 


\subsubsection{Vergi Miktarında Yapılan Hatalar}

VUK'da hesap hatası olarak düzenlenen bir diğer hata türü ise vergi miktarında yapılması durumudur. VUK'un 117/2'nci maddesinde vergi miktarındaki hatalar “Vergi nispet ve tarifelerinin yanlış uygulanması, mahsupların yapılmamış veya yanlış yapılmış olması birinci bentte yazll vesikalarda verginin eksik veya fazla hesaplanmış veya gösterilmiş olmasıdır" şeklinde belirtilmiştir. Vergi idaresi tarafından mükellef adına tarh edilen vergi miktarının doğru olması büyük ölçüde vergi matrahının tam ve doğru olmasına bağlıdır. Vergi matrahının tam ve doğru olması ise vergi mükellefinin şekli ve maddi mükellefiyetlerine sıkı sıkıya bağlı kalması halinde mümkün olabilir. Hesaplanan vergi miktarının hatalı olması büyük ölçüde vergi matrahının tam ve doğru belirlenmemiş olması ile ilgili olmakla birlikte sadece bununla ilgili değildir. Vergi mükellefinin vergi matrahı tam ve doğru iken; matraha yanlış vergi tarifesinin uygulanmış olması da vergi miktarında hatanın olmasına yol açabilir.

\subsubsection{Mükerrer Vergilendirmeden Doğan Hatalar}

Mükerrer vergilendirme veya çifte vergilendirme vergi adaletinin tesis edilebilmesi açısından oldukça önemli bir uyuşmazlık konusu olarak değerlendirilebilir. Mükerrer vergilendirme ile ilgili vergi hatası ulusal vergi sistemi ve uygulayıcılarının hatalarından kaynaklanabileceği gibi ulusal ve uluslararası vergi sistemlerinin çatışmasından da doğabilmektedir (Eva, 2016: 2). VUK'un 117/3'üncü maddesi verginin mükerrer olmasını "Aynı vergi kanununun uygulanmasında belli bir vergilendirme dönemi için ayn matrah üzerinden bir defadan fazla vergi istenmesi veya alınmasıdır" olarak değerlendirmiştir. Burada ifade edildiği gibi mükerrer bir vergilendirmenin doğabilmesi için ikinci veya daha fazla alınmak istenen verginin aynı vergilendirme döneminde aynı matrah üzerinden ve özellikle de aynı vergi türünden olması gerekmektedir. Diğer bir ifadeyle kişi gelir vergisi mükellefi ise aynı dönemde aynı matrah üzerinden ikinci defa bir gelir vergisi istenemeyecektir. Fakat aynı kişi aynı zamanda servet vergilerinin ve harcama vergilerinin mükellefi olabilmektedir. Bu durum mükerrer vergilendirme olarak değerlendirilmemektedir.

Vergilendirilen bir kazanç üzerinden aynı vergi türünün bir daha istenememesi olarak kabul edilmeyecek olan bir diğer husus da mükellefin daha önceden beyan ettiği matrah üzerinden ödediği vergiden sonra ortaya çıkan matrah farklarıdır. Örneğin; gelir vergisi mükellefi yıllık gelir vergisi miktarını ödedikten sonra yapılan tespitlerde matrah farkının ortaya çıkması halinde ek gelir vergisi tarhiyatı gerçekleştirilebilecek ve bu durum mükerrerlik oluşturmayacaktır.

\subsection{Vergilendirme Hataları}

Vergi hatalarının ikinci grubunu oluşturan vergilendirme hataları, vergi idaresi ile vergi mükellefleri arasında hesap hatalarına nazaran daha çok hukuki uyuşmazlık konusu yapılabilmektedir (Öner, 2015: 205). Vergilendirmeden kaynaklanan hataları VUK'un 118'inci maddesinde, dört başlık olarak sayılmıştır. Bunlar; mükellefin şahsında hata, mükellefiyette hata, verginin konusunda (mevzuda) hata ve vergilendirme ve muafiyet döneminde hata şeklindedir. Bu hatalar vergi mükellefiyetinin tesisini ve vergiyi doğuran olayın ortaya çıkışını etkileyebilen yanlışlıklardan oluşur. 


\subsubsection{Mükellefin Şahsında Hata}

Mükellefin şahsında yapılan hata VUK'un 118/1'inci maddesi "Bir verginin asıl borçlusu yerine başka bir kişiden istenmesi veya alınmasıdır" şeklinde ifade edilmiştir. Burada vergiyi doğuran olay ve verginin tarh ve tahakkuku bakımından hukuken sakıncalı bir işlem yoktur. Diğer bir ifadeyle ortada gerçek olan bir vergi borcu mevcuttur fakat söz konusu vergi borcunun vergi idaresi tarafindan istenmesi aşamasında ilgilisi yerine hata sonucu bir başkasından istenmesi veya alınması hali vardır. İstisnai de olsa verginin asıl borçlusu ile herhangi bir şekilde ilişkisi olmayan üçüncü kişiler nezdinde bu tarz hatalı işlemler yapılabilmektedir. Verginin asıl mükellefi ile nezdinde hatalı işlem yapılan kişinin isim benzerliği bu hatanın ortaya çıkış biçimine örnek olarak verilebilir.

\subsubsection{Mükellefiyette Hata}

Vergilendirme hatalarından mükellefiyette hatayı VUK'un 118/2'nci maddesi “açık olarak vergiye tabi olmayan veya vergiden muaf bulunan kimselerden vergi istenmesi veya alınmasıdır" şeklinde ifade etmektedir. Bu maddede diğer vergi hata türlerinden farklı olarak madde hükmüne "açık olarak" ifadesi eklenmiştir. Mükellefiyette hata kapsamında bir vergilendirme hatasında söz edebilmek için hatanın yoruma ve üzerinde tartışmaya neden olmayacak ölçüde açık olması gerekmektedir. Örneğin; gelir vergisi kanununa ticari kazanç hükümlerine göre esnaf olma şartlarını taşıyan bir kişiden gelir vergisi istenmesi mükellefiyette hatayı oluşturmaktadır. Yine benzer şekilde motorlu taşıtlar vergisi mükellefi olması gereken bir kişiden kurumlar vergisi istenmesi durumu da mükellefiyette hataya örnek olarak verilebilir.

\subsubsection{Verginin Konusunda (Mevzuda) Hata}

Vergilendirmede verginin konusunda (mevzuda) hata; VUK'un 118/3'üncü maddesinde "açık olarak vergi mevzuuna girmeyen veya vergiden müstesna bulunan gelir, servet, madde, klymet, evrak ve işlemler üzerinden vergi istenmesi veya alınmasıdır" olarak belirtilmiştir. Kanun koyucu mükellefiyette hatada olduğu gibi burada da "açık olma" hükmünü ifadeye eklemiştir.

Verginin konusu, doğrudan veya dolaylı olarak üzerine vergi konulmuş, verginin ekonomik kaynağını oluşturan ve ekonomik bir değer taşıyan mal, hizmet, servet, emek vb. unsurlardır (Enginay, 1990: 39). Bu anlamda mevzuatta olan her verginin konusu birbirinden farklı olmaktadır. Bir verginin hangi ekonomik değere sahip unsurlar üzerine konulmuş olduğunun anlaşılabilmesi için ilgili vergi kanununa bakılması gerekmektedir. Örneğin; gelir vergisinin konusu gelir vergisi kanununda yazıldığı üzere gelirdir. Motorlu taşıtlar vergisinin konusu yine ilgili kanunu olan motorlu taşıtlar vergisi kanununda yazıldığı üzere; motorlu taşıttır. Vergi konularına ilişkin istisnalar da yine ilgili vergi kanunlarında belirlenmektedir. Dolayısıyla hangi verginin konusunun ne olduğu ilgili vergi kanunlarında mükellef açısından soru işareti oluşturmayacak şekilde açık olarak yazılmalıdır. Örneğin; gelir vergisi kanunun ticari kazanç hükümlerine göre; özel eğitim kurumlarının kazançları ilk beş yıl boyunca vergi istisnası kapsamındadır. $\mathrm{Bu}$ süreçte eğitim kurumunun kazancı üzerinde vergi istenmesi verginin konusunda (mevzuda) hataya örnek olarak verilebilir. 


\subsubsection{Vergilendirme veya Muafiyet Döneminde Hata}

Vergilendirme hatalarının son türü ise vergilendirme veya muafiyet döneminde hata şeklindedir. VUK'un 118/4'üncü maddesinde vergilendirme veya muafiyet döneminde hata; "aranan verginin ilgili bulunduğu vergilendirme döneminin yanlı̧̧ gösterilmiş veya süre itibariyle eksik veya fazla hesaplanmış olmasıdır" şeklinde ifade edilmiştir. Bu vergilendirme hatası türünün iki boyutu vardır. İlk boyutu mükellefin vergilendirme döneminin vergi idaresi tarafından yanlış tespit ve tayin edilme olasılığıdır. Mükellefler açısından normal vergilendirme dönemi mali yıl olarak kabul edilen bir takvim yılına tekabül etmektedir. Fakat örneğin gelir vergisi mükellefi Bay A'nın 2019 yılının Mart ayında adi bir işletme kurup 2019 Eylül ayında bu işletmeyi kapatması durumunda, ilgili şahıs için vergilendirme dönemi "kıst dönem" olarak kabul edilecek ve faaliyette bulunduğu sürede elde ettiği kazançlar üzerinden vergi mükellefiyeti ve sorumluluğu doğacaktır. Vergi idaresince ilgili şahıs için vergilendirme döneminin bir takvim yılı olarak kabul edilerek işlem yapılması durumunda vergilendirme döneminde hata gerçekleştirilmiş olacaktır (Kızılot ve Kızılot, 2012: 119). Vergilendirmede muafiyet döneminde hata ise vergi kanunları ile belli süreliğini muafiyet tanınmış olan kişilerden hata sonucu muafiyet dönemi daha sona ermeden vergi istenmesi ve alınması şeklinde ortaya çıkabileceği gibi, ilgili muafiyet döneminin vergi idaresince yanlış hesaplanması ve belirtilmesi şeklinde de ortaya çıkabilmektedir. Örneğin; gelir vergisi kanunun ticari kazancın tespiti hükümlerine göre özel eğitim işletmesi açan bir kişiden beş yıl boyunca gelir vergisi alınmamaktadır. Çünkü bu dönem ilgili kişi için gelir vergisinden muafiyet dönemidir. 2020 yılında özel bir okul açan bir müteşebbisin gelir vergisi muafiyet dönemi 2015 yılına kadar sürecektir. 2015 takvim yılından itibaren vergilendirme dönemi başlamış olacaktır. Vergi idaresi tarafından 2015 yılının değil de 2016 yılının ilk vergilendirme dönemi olarak kabul edilmesi ve bu doğrultuda işlem tesis edilmesi muafiyet döneminde hata olarak kabul edilecektir.

\section{VERGİ HATALARININ DÜZELTILMESI YOLLARI}

Vergi hatalarının düzeltilmesi, vergi idaresi ile vergi mükellefi arasında idarenin hatalı işleminden kaynaklanan uyuşmazlık konusunun giderilmesini, ortadan kaldırılmasını ve telafi edilmesini amaçlayan idari bir süreç olarak değerlendirilebilir. Vergi hataları vergi idaresince vergilendirme işlemleri sırasında tespit edildiğinde, ilgili hatanın re'sen ve derhal düzeltilmesi mümkün olabilmektedir. Fakat uygulamada düzeltme konusu olan hatalar, sonradan vergi idaresince veya vergi mükelleflerince tespit edilmiş olan hatalardır (Yüce, 2019: 97). VUK 119'uncu maddeye göre, vergi hataları aşağıdaki yollarla tespit edilebilmektedir.

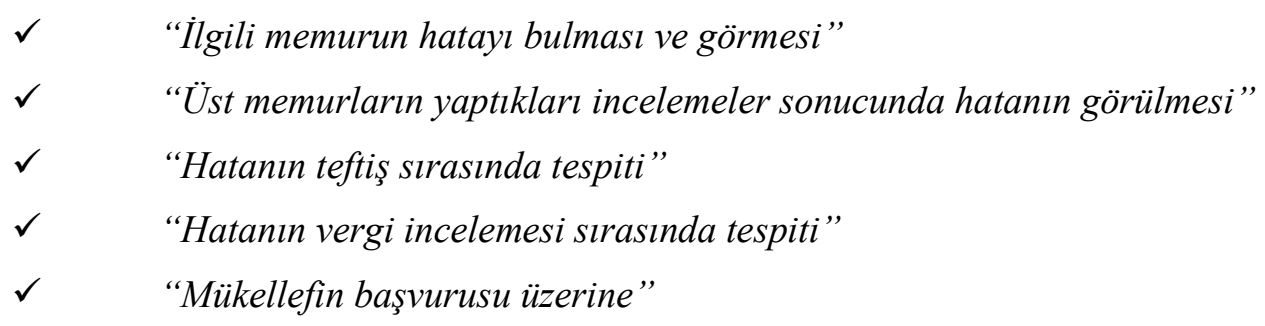

Yukarıda sayılan yollarla vergi hataları tespit edilebilmekte ve gerekli düzeltme işlemleri vergi idaresince uygulanabilmektedir. Vergi uyuşmazlığına neden olan vergi hatası tespit yolu 
ise daha hatanın daha çok "mükellefin başvurusu üzerine" tespit edilmesidir. Vergi hataları iki şekilde düzeltilebilmektedir. Bunlar; hatalı işlem yapan vergi idaresince ilgili düzeltmenin yapılarak vergi uyuşmazlık konusunun ortadan kaldırılması ve hatalı işlem vergi idaresince kaldırılmadığında; mükellefin vergi yargısına başvurması suretiyle ilgili vergi hatasının ortadan kaldırılmasıdır.

\subsection{Vergi Hatalarının Vergi Dairesince Düzeltilmesi}

Nezdinde hatalı vergilendirme işlemi yapılan mükellef, kendisine vergi veya ceza tebligatı yapılması üzerine hatayı fark etmekte ve bunu vergi idaresine karşı ileri sürebilmektedir. Düzeltme, vergi hatalarının yargı organlarına başvurulmaksızın, hatanın ilgili vergi dairesince ortadan kaldırılmasına yönelik yapılan idari bir işlemi ifade etmektedir. Duruma göre, düzeltme ile ilgili başvuruların, sonradan yargıya intikal etmesi mümkün olabilmektedir (Ufuk, 2002: 40). Vergi hatas1 olduğu ileri sürülen durumun ilgili mükellef tarafından tespit edilmesi halinde söz konusu hatanın düzeltilmesi mükellef tarafından yazılan bir dilekçe ile işlemi gerçekleştiren vergi dairesinden talep edilir. Mükellefin bağl1 bulunduğu vergi dairesi veya hatalı işlem yaptığı ileri sürülen vergi dairesi, mükellefin yazılı olarak yapmış olduğu hatanın düzeltilmesi talebini inceleyerek karara bağlar. Bu karar sonucunda, mükellefin düzeltme talebi ya yerinde görülerek kabul edilip hatalı işlem düzeltilecektir ya da talebi uygun bulunmayarak reddedilecektir. İlk sonucun çıkması durumunda vergi idaresi ile vergi mükellefi arasındaki vergi uyuşmazlığ konusu da ortadan kalmış olacaktır. Fakat ikinci sonucun yani hata düzeltme talebinin reddolunması durumunda uyuşmazlık konusu devam etmiş olacaktır. Bu takdirde ise nezdinde hatalı işlem yapılan ve ilgili vergi dairesince düzeltme talebi reddedilen mükellef şikâyet yolu ile konuyu Hazine ve Maliye Bakanlığı'na taşıyabilecektir.

VUK 120'inci maddesi uyarınca; vergi hatasının hangi yolla tespit edildiği fark etmeksizin, vergi hatalarının düzeltilmesi yetkisi hatalı işlemi yapan vergi dairesi müdürüne aittir. Vergi dairesi müdürü, yapılan inceleme sonucunda vergilendirme işleminde vergi hatasının bulunduğunu tespit ederse ilgili işlemdeki hatanın düzeltilmesini sağlayacaktır. Vergi hatasını düzeltme yetkisi vergi dairesi müdürüne ait olduğu gibi mükellefin düzeltme talebini reddetme yetkisi de ilgili vergi dairesi müdürüne aittir. Yapılan incelemeler neticesinde düzeltme kararı verilirse düzeltme işlemi düzeltme fişi aracılığıyla gerçekleştirilecektir. Uygulamada vergi düzeltme fişleri üç nüsha halinde düzenlenmekte ve bir nüshası mükellefe tebliğ edilmektedir. Kalan iki nüsha ise mükellefin dosyasında saklanmakta ve vergi dairesindeki muhasebe servisi ile paylaşılmaktadır. Vergi dairesi tarafından mükellef aleyhine hatalı yapıldığı tespit edilen işlem söz konusu ise buna binaen terkin ve tahsili gerçekleştirilmiş ise fazla vergi mükellefe reddolunur. Mükellefe tebliğ edilen düzeltme fişi ile reddolunan miktar, mükellefin müracaat edeceği muhasebe servisi ve müracaat süresi belirtilir. Mükellefin kendisine tebliğ edilen düzeltme fişine dayanarak tebliğ tarihinden itibaren bir y1l içerisinde fazla ödediği vergi miktarını geri alması için başvuru yapması gerekmektedir. İlgili süre hak düşürücü süre olarak kabul edildiğinden mükellefin reddolunan vergi miktarını almak için süresinde başvurmaması durumunda bu hakkı düşecektir. Mükellef bir yıl içerisinde fazla ödediği vergiyi geri alabileceği gibi yine aynı sürede belirtilen müracaat yerine başvurarak reddolunan vergi miktarının başka vergi borçlarından mahsup edilmesini de talep edebilir. 
Nezdinde hatalı işlem yapılan vergi mükellefinin düzeltme talebinin ilgili vergi dairesi tarafindan uygun bulunmaması ve reddedilmesi durumunda (mükellefin ilgili vergi dairesine başvurmuş olduğu tarihten itibaren 60 gün içerisinde kendisine vergi dairesi tarafından herhangi bir tebligat yapılmamışsa talep zımnen reddedilmiş sayılır) bu durum ilgili mükellefe yazılı bir biçimde tebliğ edilir. Düzeltme talebinin vergi dairesince reddedilmesi durumunun, 30 günlük vergi mahkemesine başvurma süresi dâhilinde mükellefe tebliğ edilmesi halinde mükellef kalan dava açma süresi içerisinde vergi dairesinin hatalı işlemine karşı vergi mahkemesinde dava açabilecektir.

Düzeltme zamanaşımı süresi, vergi hukukundaki genel zamanaşımı süresi ile aynıdır. VUK 114'üncü maddesine göre; “vergi alacă̆ının doğduğu takvim yılını takip eden yılın başından başlayarak beş yıl içinde tarh ve mükellefe tebliğ edilmeyen vergiler zamanaşımına uğrar". Söz konusu beş yıl içerisinde hatalı olan işlemle ilgili herhangi bir düzeltme talebi ve işlemi gerçekleştirilmez ise; yapılan işlem hatalı dahi olsa o işlemi bir daha düzeltebilme imkânı olmayacaktır. Fakat VUK'un 126'ıncı maddesi uyarınca aşağıdaki durumlarda bir yılda az olmamak üzere ek süre öngörülmüştür.

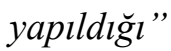 \\ "Zamanaşımı süresinin son yılı tarh ve tebliğ edilen vergilerde hatanın \\ "Ilan yoluyla tebliğ edilip, dava konusu yapılmaksızın tahakkuk eden vergilerde mükellefe ödeme emrinin tebliğ edildiği $"$}

$\checkmark \quad$ "Ihbarname ve ödeme emri ilan yoluyla tebliğ edilen vergilerde haczin yapıldiğı tarihten başlayarak zamanaşımı süresine bir yıldan az olmamak kaydıyla süre eklentisi yapılacaktır."

\subsection{Vergi Hatasının Şikâyet Yolu İle Düzeltilmesi}

VUK 124'üncü maddesi hükmüne göre; nezdinde hatalı işlem yapılan vergi mükellefleri, hatanın düzeltilmesi talebinde bulundukları vergi dairesinden taleplerinin reddedilmiş olduğunu kendilerine yapılan tebligat ile öğrendiklerinde vergi mahkemesinde dava açma süresi olan 30 günlük sürenin dolmuş olması durumunda "şikâyet yolu” ile Hazine ve Maliye Bakanlığı'na başvurabilmektedirler. $\mathrm{Bu}$ düzeltme başvurusu yolu, dava açma süresinde vergi dairesinin mükellefe cevap vermemiş olması sebebiyle "mükellefin haklarını" gözetmek amacıyla kanun koyucu tarafından geliştirilmiş ve mevzuata dâhil edilmiştir. Vergi dairesince aleyhine hatalı bir işlemin yapıldığı düşünen mükellef, vergi dairesince düzeltme talebinin reddedildiği kararı kendisine dava açma süresinde tebliğ edilmediğinden dava açma hakkını kullanamayacaktır. Mükellefin mağdur olmaması için hakkında düzeltme işlemini gerçekleştirmeyen vergi dairesini üst mercii olan Hazine ve Maliye Bakanlı̆̆ı'na şikâyet edebilmektedir. Mükellefin hatanın şikâyet yolu ile düzeltilmesi talebini de yazılı olarak yapması gerekmektedir. Hazine ve Maliye Bakanlığı mükellefin düzeltme talebini inceleyerek bir karar verecektir. Bakanlık tarafından mükellefin talebi yerinde bulunursa hatanın düzeltilmesi işlemi nihai olmak üzere gerçekleştirilecektir. Düzeltme kararı ilgili Vergi Dairesi Başkanlığı'na veya Defterdarlığa yazı ile bildirilir. İlgili makam da gerekli düzeltme işlemlerini yaparak, düzeltme fişini düzenleyerek mükellefe tebligatta bulunur. Bakanlık tarafından mükellefin hatanın düzeltilmesi talebi yerinde bulunmazsa veya mükellefin Bakanlığa başvuru tarihinden itibaren 60 gün içerisinde herhangi 
bir cevap verilmezse başvuru zımnen reddedilmiş sayılarak, vergi idaresi tarafından ortada hatalı bir işlemin var olmadığı sonucuyla hata düzeltme işlemi yapılmamış olacaktır. Bu andan itibaren mükellef konuyu idari dava yoluna taşıyabilecektir (Yüce, 2019: 97).

\subsection{Vergi Hatasının Vergi Yargısında Düzeltilmesi}

İdare ile kişiler arasındaki uyuşmazlık konularına ilişkin yargılamayı yapan merciiler idari yargı mercileridir. Söz konusu yargılamanın usul ve esaslarını ise 2577 Sayılı İdari Yargılama Usulü Kanunu (IYYK) belirlemektedir. Vergi davaları da idari davalardan olduğuna göre bu kanun hükümlerine tabidir. IYYUK'un 11 'inci maddesine göre; "ilgililer tarafindan idari dava açılmadan önce idari işlemin kaldırılması, geri alınması, değiştirilmesi veya yeni bir işlem yapılması üst makamdan, üst makam yoksa işlemi yapmış olan makamdan dava açma süresi içinde istenebilir. Bu başvurma işlemeye başlamış olan idari dava açma süresini durdurur”. Dolayısıyla vergi hatasının varlığı ve hatanın düzeltilmesi gerekçesi ile ilgili vergi dairesine ve şikâyet yoluyla Hazine ve Maliye Bakanlığı'na başvuruda bulunan mükellef açısından talebinin reddedildiğinin kendisine tebliğ edildiği süreye kadar vergi davası açma süresi duracaktır. Tebliğin yapıldığı gün itibariyle işlemeyen süre kadar dava açma süresi işleyemeye devam edecektir. Mükellefe düzeltme başvurusundan itibaren 60 gün içerisinde herhangi bir cevap verilmemiş olması durumunda düzeltme talebi zımnen reddedilmiş sayılacağından, dava açma süresi düzeltme başvurusunun yapıldığı günden itibaren 60 gün duracaktır. Nitekim aynı maddenin 3'üncü fikrasında; "isteğin reddedilmesi veya reddedilmis sayılması halinde dava açma süresi yeniden işlemeye başlar ve başvurma tarihine kadar geçmiş süre de hesaba katılır" denilmek suretiyle bu husustan bahsedilmiştir.

Vergi hatasının mükellefin yazılı talebi neticesinde ilgili vergi dairesince ve sonrasında şikâyet yolu ile Hazine ve Maliye Bakanlığı'na başvurusu üzerine düzeltilmemesi durumunda mükellef vergi mahkemesine iptal davası açabilecektir. Vergi mahkemesi açılan ve görülen dava neticesinde iki karara hükmedebilecektir. Vergi mahkemesi mükellefi haklı bularak vergi dairesince yapılan işlemin hatalı olduğu sonucuna vararak söz konusu idari işlemi iptal edebilir. Veyahut vergi mahkemesi vergi dairesinin işleminin hatalı olmadığını ve bu gönde almış olduğu kararını onaylayarak idare lehine ve mükellef aleyhine hükme varabilir.

Mükellefin hatalı vergilendirme işlemine karşı vergi mahkemesinde açmış olduğu dava; dava konusu meblağın miktarına göre ya tek hâkimle ya da üç hâkimle görülmektedir. Tek hâkimle görülen dava sonucunda mükellef aleyhine sonuçlanan karara karşı 30 gün içerisinde, mükellef itiraz (istinaf) yolu ile Bölge İdare Mahkemesi'ne (İstinaf Mahkemesi) başvurabilir. $\mathrm{Bu}$ durumda Bölge İdare Mahkemesi'nin vereceği karar nihai karar olup kesinleşecektir. Vergi mahkemesinin kurul halinde mükellef aleyhine ve idare lehine vermiş olduğu karar için ise; mükellef Danıştay'a temyiz yolu ile başvurabilecektir. Danıştay’ın uyuşmazlık konusu ile ilgili vereceği karar da nihai olup taraflar için kesin hüküm ifade edecektir.

Nezdinde hatalı işlem yapıldığı düşünen vergi mükellefi kendisine tebliğ edilen vergi veya vergi cezasına karşı, tebliğ tarihinden itibaren 30 gün içerisinde vergi idaresine düzeltme için başvurma yolunu tercih etmeyerek doğrudan vergi mahkemesinde dava açma hakkına sahiptir. Fakat bu durumda dava açma maliyetlerini de üstlenmiş olacaktır. Açılan dava 
neticesinde, vergilendirme ile ilgili hatalı bir işlemin var olmadığı sonucuna ulaşılması durumunda mükellefin aleyhine bir kararın verilme olasılığı da bulunmaktadır.

\subsection{Vergi Hatasının Düzeltilmemesi}

Vergi hatalarının düzeltilmesi hem vergi idaresinin hem de mükelleflerin haklarının korunabilmesi açısından önem arz etmektedir. Söz konusu hatalar kimi zaman vergi idaresi lehine mükellef aleyhine, kimi zaman ise; vergi idaresi aleyhine mükellef lehine doğabilmektedir. Ve her iki durumda uyuşmazlık konusunu ortaya çıkarabilmektedir. Vergi hatalarından kaynaklanan uyuşmazlık konularının idare tarafından re'sen düzeltilmesi veya mükellefin başvurusu üzerine düzeltme işlemlerinin gerçekleştirilerek uyuşmazlık konusunun ortadan kaldırılması istenilen ve beklenilen iki durumdur. Vergi hatalarından kaynaklanan uyuşmazlık konusunun her iki biçimde de vergi idaresi tarafından düzeltilmesi hem idare ile mükellef arasında sulh durumunun korunabilmesine hem de vergilendirmeye esas teşkil eden olayın gerçek mahiyetinin ortaya çıkarılmasına yol açabilmektedir. Vergi hatasından kaynaklanan uyuşmazlık konusunun vergi idaresi tarafından çözümlenememesi durumunda konu vergi yargısına taşınabilmekte bu durum hem vergi yargısının iş yükünü çoğaltabilmekte hem de her iki tarafa da çeşitli maliyetler yükleyebilmektedir.

213 Sayıl1 VUK'un 3'üncü maddesinde; "vergilendirmede vergiyi doğuran olay ve bu olaya, ilişkin muamelelerin gerçek mahiyeti esastır" denilerek, vergilendirme ile ilgili yapılan işlemlerin gerçek durumlarının ortaya çıkarılmasının vergi idaresi tarafından amaç edinilmesi gerektiği ifade edilmiştir. Vergi idaresi tarafından yapılan işlemde vergi hatası olması durumunda ve ne re'sen ne de mükellefçe idareye yapılan müracaat sonucunda bu hatalı ve uyuşmazlık konusu olan işlemin kaldırılmaması; vergilendirmenin temelini oluşturan işlemin gerçek mahiyetinin kavranamaması ve ekonomik olayın tam manasıyla saptanamaması sonucunu doğurabilecektir. Dolayısıyla verginin tarh, tahakkuk ve tahsilinde hatadan dolayı yaşanabilecek eksiklikler hazineye olması gerekenden daha az veya daha fazla verginin intikal ettirilmesine neden olabilecektir. Vergi idaresi tarafından hatalı işlemin bir an önce tespit edilerek ortadan kaldırılamaması yukarıda ifade edilen kanun maddesi hükmüne aykırılık taşıyacaktır.

Diğer taraftan Anayasa'nın “vergi ödevi” başlıkl1 73’üncü maddesinin ikinci bendinde; "vergi yükünün adaletli ve dengeli dağllımı, maliye politikasının sosyal amacıdır" ifadesi yer almaktadır. Bu madde hükmü gereğince; vergi politikaları ile sosyo-ekonomik anlamda adil bir dengenin kurulması amaçlanmaktadır. Vergi yükünün toplumda adaletli ve dengeli dağılması, gelir dağılımının da toplumsal tabakalar arasında nispeten daha kötü durumda olanların lehine iyileşmesi anlamına gelmektedir. Vergi hatalarından kaynaklanan bir uyuşmazlı̆̆ın derhal veya hiç giderilememesi veya vergi yargısına taşınarak zaman kaybının yaşanması, vergi kayıp ve kaçağının ortaya çıkabilmesine ve bu nedenle de toplumdaki vergi yükünün adaletli ve dengeli dağılamaması sonucunun oluşmasına neden olabilir. Dolayısıyla vergi hatalarının düzeltilememesi Anayasa'nın 73'üncü maddesine aykırılık teşkil edebilecektir. Vergi hatalarının düzeltilmesinde önemli olan hatalı bir işlem geç̧ekten varsa bu işlemin sonuçlarıyla birlikte vergi idaresi tarafindan derhal ortadan kaldırılması olmalıdır. Aksi durumda hem vergi idaresi hem de vergi mükellefleri birtakım kayıplar yaşayabilmektedir. 


\section{SONUC}

Vergi politikalarının uygulanabilmesinin ve vergilendirme sürecinin esaslarından biri kamu otoritesini temsil eden vergi idaresi ile vergi mükellefi olan kişiler arasındaki "güven" duygusunun tesis edilebilmesi oluşturmaktadır. Süreklilik arz eden söz konusu karşılıklı ilişkide tarafların birbirlerine karşı anlayış içerisinde olmaları, süreci kolaylaştıran bir etkiye sahiptir. Vergi alacaklısı konumunda olan vergi idaresi vergi mükelleflerinden mümkün olduğu kadar vergi tahsil edebilme gayesi güderken; vergi borçlusu durumunda bulunan vergi mükellefleri ise mümkün olduğu kadar az vergi ödeme eğiliminde olabilmektedirler. Bu şartlarda her iki taraf arasında zaman zaman birtakım uyuşmazlıklar ortaya çıkabilmektedir. Önemli olan söz konusu uyuşmazlık konularının ivedi biçimde karşılıklı anlayış içerisinde ortadan kaldırılması ve karş1l1kl1 "güven" duygusunun bundan zarar görmesinin önüne geçilebilmesidir.

Vergi uyuşmazlıkları kavramı; vergi idaresi ile vergi mükellefleri arasında verginin maddi ve şekli unsurlarına dair tüm işlemlerle ilgili anlaşmazlık durumunu belirtmektedir. Çünkü söz konusu vergilendirme işlemleri ile birlikte kişilere bir maliyet yüklenilmek istenilmektedir. Bu maliyete katlanmak istemeyen mükellefler konu ile ilgili itirazlarını yetkili mercilere ulaştırabilme çabasına girebilmektedirler. Vergilendirme işlemleri genel anlamda tek taraflı işlemler oldukları için potansiyel anlamda vergi mükellefi olan kişilerin bu işlemlere karşı itiraz edebilme durumları her zaman mevcuttur.

Vergi hataları ise; vergi alacaklısı vergi idaresi ile vergi borçlusu vergi mükellefleri arasında ortaya çıkabilen uyuşmazlık konularının bir kısmını oluşturmaktadır. Vergilendirme işlemleri genel olarak tek taraflı biçimde vergi idaresi tarafından yürütüldüğünden ve pek çok vergi mükellefine ilişkin işlemler gerçekleştirildiğinden zaman zaman hatalı işlemlerin yapılabilmesi olasıdır. Vergi hataları iki grupta incelenmiştir. Bunlar hesap hataları ve vergilendirme hatalarıdır. İlgili hatalar vergi idaresinin lehine vergi mükellefinin aleyhine sonuç doğurabilecekleri gibi vergi idaresinin aleyhine vergi mükellefinin lehine de sonuç doğurabilmektedirler. Amaç; hangi tarafın lehine veya aleyhine olduğundan ziyade ortada hatalı bir işlemin tespiti ve bu işlemin tarafların mağduriyetine neden olmadan tüm sonuçları ile birlikte derhal ortadan kaldırılabilmesidir.

Vergi hataları, işlemleri gerçekleştiren vergi idaresi tarafından re'sen tespit edilerek düzeltilebileceği gibi kendisine hatalı işlem tebligatı yapılan vergi mükellefi tarafından da tespit edilebilir. Böyle bir durumda nezdinde hatalı işlem gerçekleştirilen mükellef yazılı olarak ilgili vergi dairesine düzeltme talebinde bulunabilmektedir. Düzeltme işlemlerinin geciktirilmeksizin gerçekleştirilerek vergilendirmenin gerçek durumunun vergi dairesi tarafından tespit edilip ortaya çıkartılması gerekir. Nihayetinde hatalı işlemler vergi tarhiyatının ve tahsilinin de hatalı gerçekleştirilmesine zemin hazırlayabilir. Fakat vergi daireleri ne re'sen ne de mükellefin yazılı başvurusu üzerine tespit edemeyebilirler. Yapılan işlemin doğru olduğunu ve herhangi bir hatanın olmadığını ileri sürebilmektedirler. Dava açma süresinin geçmiş olması halinde vergi mükellefleri bu durumu şikâyet yolu ile Hazine ve Maliye Bakanlığı'na yazılı başvuru ile iletebilmektedirler. Hazine ve Maliye Bakanlığı'nca hatalı işlemin tespit edilmesi ve ilgili vergi dairesine düzeltme işlemlerinin yapılması için yazılı talimatın gönderilmesi beklenir. Hazine ve 
Maliye Bakanlığı tarafından da mükellefin düzeltme talebinin reddedilmesi durumunda kendisine konunun tebliğ edildiği tarihten itibaren mükellefin uyuşmazlık konusunu vergi yargısına taşıması gerekmektedir. Nihayetinde yargı süreci nihai kararı vermiş olacaktır.

Vergi hatalarının düzeltilmesi işlemlerinin, vergi adaletinin tesis edilebilmesi ve mükellefin hak ve hukukunun korunabilmesi ve telafi mekanizmasının bir an önce işletilebilmesi adına hatalı işlemi gerçekleştiren vergi dairesi tarafından gerçekleştirilmesi gerekmektedir. Düzeltme işlemlerinin uzatılması ve sürecin sarkması durumunda mükellefin mağduriyeti de artmış olabilmektedir. Vergi dairesi işlemde ısrarcı ise düzeltme talebinin reddi cevabını mükellefin hakkını arayabilmesi amacıyla derhal mükellefe bildirmesi yerinde olacaktır. Talebi reddedilen mükellef yine idari çözüm yolu olan şikâyet yoluna başvurabilecektir. Eğer vergi hataları bu aşamada çözülürse uyuşmazlık konusu vergi yargısına intikal ettirilmeden ve taraflara dava maliyetleri ile vergi yargısına iş yükü yüklenilmeden sorun ortadan kaldırılmış olacaktır. Fakat Hazine ve Maliye Bakanlığı da mükellefin hata düzeltme talebini reddederse mükellefin vergi uyuşmazlıklarında ilk derece mahkemesi olan vergi mahkemesine müracaat etmekten başka çaresi kalmayacaktır.

Vergi uyuşmazlıklarında önemli olan husus vergi idaresi ile mükelleflerin barışçıl yollarla sorunu giderebilmeleri ve karşılık güven duygusunun tahrip edilmemesidir. Vergi idaresinin hatalı bir işlemin varlığına rağmen uyuşmazlık konusu işlemi ortadan kaldırmamakta direnmesi VUK'un 3'üncü maddesine ve Anayasa'nın 73/2'inci maddesine aykırılık teşkil edecektir.

\section{KAYNAKÇA}

Çamlı, A. Y. (2020). Yeni Bir Toplum Kuram Dinamiği: Pratik-Rasyonellik. Kocatepe İIBB Dergisi, 22 (1), Afyon.

Çamlı, A. Y. (2020a). Ikktisadi Eşitsizlikler Giderilerek Iktisadi Adalet Sağlanabilir mi? Piyasa Toplumunun Sosyo-Felsefik Bir Eleştirisi. İstanbul: Hiper Yayınevi.

Demirel, M. (2016). Vergi Hataları Ve Düzeltme Yolları. Yüksek Lisans Tezi, Okan Üniversitesi Sosyal Bilimler Üniversitesi. İstanbul.

Enginay, A. (1990). Kamu Maliyesi. Ankara: Savaş Yayınları.

Eva, E. (2016). Tax Conflicts In The Light of the European Tax Harmonization. MultiScience $X X X$. microCAD International Multidisciplinary Scientific Conference University of Miskolc, Hungary.

Keene, M. ve Thomson, P. (2007). An Analysis of Tax Revenue Forecast Errors. New Zealand Treasury Working Paper, 7 (2), 2, New Zealand.

Kızılot, Ş. ve Kızılot, Z. (2012). Vergi Uyuşmazlıkları ve Çözüm Yolları. Ankara: Yaklaşım Yayincilik.

Öncel, M., vd. (2014). Vergi Hukuku. Ankara: Turhan Kitabevi.

Öner, E. (2015). Vergi hukuku. Ankara: Seçkin Yayınc1lı. 
Perçin, N. (2007). Vergi hatası ve vergi uyuşmazlığ1 fark1, vergi hatalarında düzeltme ve reddiyat. Mali Çözüm Dergisi,79, 156, İstanbul.

Ufuk, M. T. (2002). Vergi İhtilaflarının, İdari Aşamada Çözüm Yolları. Maliye ve Sigorta Yorumları Dergisi,356, 40, Ankara.

Yüce, M. (2019). Vergi Yargllama Hukuku. Bursa: Ekin Kitabevi.

213 Say1l1 Vergi Usul Kanunu

2577 Sayılı İdari Yargılama Usulü Kanunu

193 Sayılı Gelir Vergisi Kanunu 